\section{Design Practice and Scholarly Research Combining the Best of Both Worlds}

Katelijn Quartier

Hasselt University

\section{INTRODUCTION}

Establishing new academic programs is a long-term process. Short-term but intensive programs, as a summer school for example, are easier in setting up and can also be used as experimental hubs (thinker spaces). To this end, in 2014, we started to organize a summer school in, what we call, 'Seamless Retail Design' in cooperation with Technical University of Delft (TUD) and Politectnico di Milano (Polimi). We presented the students with the challenge to create retail environments which seamlessly combine the spatial (physical environment), the digital and the human (experiential) factor. This challenge is not chosen randomly. Indeed, today, three clear phenomena have changed the way retail needs to be done drastically. Firstly, consumers are more aware of their own buying behavior which reflects on their shopping behavior. Secondly, the scarce time people have and want to spend on shopping, they wan't to spend it in a nice environment (Quartier, 2017). The third phenomenon is related to the digital revolution, which has changed consumer behavior profoundly. Creating holistic and seamless brand experiences, which transcend the boundaries of online and offline channels is crucial (Rigby, 2014; Van Ossel, 2014; van Tongeren, 2013).

So, the fundamental change in the context within which retailers will have to function today and in the near future also asks for a different design approach: how we design stores has changed from a merely design perspective to a more multi-disciplinary one (Zimmerman and Teufel, 2015). To this end, we set up the summer school as an experimental environment in which students from different backgrounds and disciplines, though, with a relation to retailing and design (e.g. interior design, architecture, product design, marketing, graphic design and media design), can collectively reflect on the challenges and opportunities of the store of the future.

\section{EVOLUTION SUMMER SCHOOL SET-UP}

\section{THE FIRST THREE YEARS (2014-2016)}

During the first three years, after a selection process, the summer school received subsidies from Study in Flanders. During those three years the summer school was organized during two weeks. The aim was to close the gap, which was explicitly present at that time, between the offer in educational programs on retailing and design. Concerning the retail educational offer in Europe, two perspectives were found - one of design and one of marketing. While retail design is often characterized as a design discipline closely related to, or as a sub field of interior design, having a rather conservative approach, the marketing perspective is primarily theoretically oriented and offers limited insight nor skill building in how to implement retail strategies into an actual store design (see Quartier, Lommelen, Vanrie, 2016, 31-49, for a more extended review). We saw the opportunity in the void on the crossover of theory \& practice, and retail design \& marketing. Indeed, in order to fully grasp the evolutions and to come up with effective stores an interdisciplinary approach (integrating 
knowledge and methods from different disciplines, using a real synthesis of approaches) seemed to be the answer. The more so because in practice, the advantages of such an interdisciplinary approach were already widely accepted by retail design companies which include cross-channel design in their service. They rely on a wide range of specialized designers such as product-, graphic-, web- and interior designers that cooperate intensely to come to desired and valuable designs. Moreover, non-designers like psychologists and sociologists are invited to the team to better understand and service the audience they are jointly designing for.

The program typically consisted of morning sessions where students are introduced to state-of-the-art knowledge brought by academics and experienced practitioners regarding four major themes: retail design, marketing, digital media and future trends. In the afternoon, the students actively engaged in a design workshop in the multidisciplinary teams we composed. Each day, the teachers of the morning sessions assisted in supervising the afternoon sessions to ensure an optimal integration of knowledge transferred in the morning. Furthermore, students were inspired with field trips to Brussels, Antwerp and particular innovative sites where examples of strong designs in line with retail 3.0 (retail after the crisis of 2008) could be found.

\section{THE LAST THREE YEARS (2017-2019)}

After the succes of the first three years, we took a leap and continued organizing the summer school even though the subsidies ended. To keep the summer school affordable we changed the format into a crash course of one week. We also enlarged the possible target group, by making the summer school open to not only students but also young professionals. Additionally, the following changes were made (see table 1):

- a sponsor was added to give a real life assignment on the one hand, and co-financing on the other.

- The experiment, we did in the third year of organizing the summer school, in which wok-shops of a whole day were included (in stead of theory in the morning and design studio in the afternoon) was further implemented due to its succes. So rather than having a lecture of half a day, the teacher focused on an interactive session with small exercises during the day, leading to building blocks for the final design.

- The teaching team evolved from a 50/50 balance professor versus experts from practice, to a $80 / 20$ balance due to the time frame of one week and the addition of a sponsor. This shift was only possible because we started to developed design tools based on expert insights. These tools help the professor to integrate the multi-disciplinary approach without having the full multi-disciplinary teaching team as we had during the first three years.

Table 1. Evolution of the summer school during six years.

\begin{tabular}{|c|c|c|c|c|c|c|}
\hline EDITION & costs & TIMING & SET-UP & TEACHING TEAM & KNOWLEDGE & ASSIGNMENT \\
\hline \multirow[t]{5}{*}{$\begin{array}{c}\text { 1st edition } \\
\text { (summer 2014) }\end{array}$} & Subsidized & 2 weeks & $\begin{array}{l}\text { Theory in morning, } \\
\text { practice in afternoon }\end{array}$ & $\begin{array}{l}\text { 50/50 Prof. vs experts } \\
\text { from practice* }\end{array}$ & Expert insights & $\begin{array}{l}\text { Fictive } \\
\text { assignment }\end{array}$ \\
\hline & Subsidized & 2 weeks & $\begin{array}{l}\text { Theory in morning, } \\
\text { practice in afternoon }\end{array}$ & $\begin{array}{l}50 / 50 \text { Prof. vs experts } \\
\text { from practice }\end{array}$ & Expert insights & $\begin{array}{l}\text { Fictive } \\
\text { assignment }\end{array}$ \\
\hline & Subsidized & 2 weeks & $\begin{array}{l}\text { Theory in morning, } \\
\text { practice in afternoon } \\
+\mathbf{2} \text { work-shop days }\end{array}$ & $\begin{array}{l}\text { 50/50 Prof. vs experts } \\
\text { from practice }\end{array}$ & Expert insights & $\begin{array}{l}\text { Fictive } \\
\text { assignment + } \\
\text { real location }\end{array}$ \\
\hline & $\begin{array}{l}\begin{array}{l}\text { Self-sufficient } \\
\text { (+sponsor) }\end{array} \\
\text { (t) }\end{array}$ & 1 week & $\begin{array}{l}\text { 2 work-shop days } \\
\text { (external) }\end{array}$ & $\begin{array}{l}\text { 60/40 Prof. vs experts } \\
\text { from practice + Retailer }\end{array}$ & $\begin{array}{l}\text { Start development } \\
\text { design tools }\end{array}$ & $\begin{array}{l}\text { Real } \\
\text { assignment }\end{array}$ \\
\hline & $\begin{array}{l}\text { Self-sufficient } \\
\text { (+sponsor) }\end{array}$ & 1 week & $\begin{array}{l}1 \text { work-shop day } \\
\text { (external) }\end{array}$ & $\begin{array}{l}\text { 80/20 Prof. vs experts } \\
\text { from practice + Retailer }\end{array}$ & $\begin{array}{l}\text { Implementation } \\
\text { design tools }\end{array}$ & $\begin{array}{l}\text { Real } \\
\text { assignment }\end{array}$ \\
\hline $\begin{array}{c}\text { 6th edition } \\
\text { (summer 2019) }\end{array}$ & $\begin{array}{l}\text { Self-sufficient } \\
\text { (+sponsor) }\end{array}$ & 1 week & $\begin{array}{l}3 \text { work-shop days } \\
\text { (internal+external) }\end{array}$ & $\begin{array}{l}\text { 80/20 Proft vs experts } \\
\text { from practice + Retailer }\end{array}$ & $\begin{array}{l}\text { Design tools are } \\
\text { key }\end{array}$ & $\begin{array}{l}\text { Real } \\
\text { assignment }\end{array}$ \\
\hline
\end{tabular}

\section{OBJECTIVES}

During the last years we have developed a steady program and framework in which three objectives are key:

- working in interdisciplinary teams of both students and teachers

- combining expertise from practitioners with theoretical input from researchers

- working with a real life design assignment

\section{IMPLEMENTATION}

The first objective, the interdisciplinary character, we guard by composing an interdisciplinary teaching team on the one hand, and recruit students and young professionals from different disciplines, on the other. We managed to get a large variety of disciplines each year (e.g. interior architecture, architecture, product design, environmental design, fashion design, marketing, Management \& Technology, MBA, etc.). Also many different cultural backgrounds are present. During the last edition students as far as from Hong Kong and Brazil participated.

The experts (from practice) we invite to host a work-shop are selected carefully: one product developer teaching the students a consumer-centred approach; a marketeer/brand designer, helping the students to get a grip on branding; and several retail designers helping the students to translate the concept into a feasible design.

As for the students, they work in small, heterogeneous groups, interdisciplinary teams that are carefully composed based on the their study background. Hence, the learning curve does not only come from experts, it also comes from the interaction within a group.

The second objective, combining expertise, is inherent present in the program we offer. Students are introduced to state-of-theart knowledge from both academics and experienced practitioners during design work-shops. And, the students are coached in the design studio by a team of local and international design supervisors. A researcher, part of our team, curates the designworkshops and small design assignments that help building up the design from idea, to concept, to design.

We want students to reflect on the store of tomorrow. To this end, for our third objective, each year we select a large scale local retailer that has a need that fits our program: a new (concept) store, integrating all media. By having students from a different social contexts and from various relevant disciplines collaborating on such a concrete design assignment, we wish to come to refreshing and innovative 
ideas. The retailer actively takes part in the program by feeding our students with the necessary knowledge and insights, and be part of the jury (which is set up as a pitch) at the end of the summer school providing the students with valuable feed-back.

\section{OUTCOME}

The intended outcome for the summer school as it is the last couple of years, is dual. Of course, firstly, it is to come up with fresh ideas for the store of tomorrow in general, and with a design of it for the sponsoring retailer. Secondly, on students behalf, we aim for the following competencies to be achieved:

- the students are familiar with 'retail design' as a multidisciplinary domain

- students learn to collaborate with students from other disciplines and backgrounds on concrete assignments

- students learn to convert (state-of-the-art) knowledge from practice and research into relevant innovative concepts and designs in a relatively short period of time

- by confronting them with international teachers and the cooperating and living together with an international group of students, they acquire intercultural skills.

\section{EVALUATION}

Based on the evaluations, we see that we have developed a successful formula. Indeed, each year the summer school is assessed by the students through a survey, while the academic stakeholders and the practitioners are interviewed. The evaluations are conducted one week after the end of each summer school. The results improve each year (which of course is the ambition since we actually act upon the feed-back we receive), leading to very positive feed-back after the last edition in 2018 (edition 2019 will start August 21). A critical assessment of the last two editions indicated that the strong elements of the summer school set-up are its inter-disciplinary and the international character; and the cross-over between research and practice by feeding the students with both academic knowledge - giving them insights in the latest research results - as practice - providing them design methodologies and thinking models. Finally, the workshop formule, tools offered, and the strict timing, with the partial assignments cumulating into one design were very much appreciated.

What remains a challenge though, seems to be the difficulty of designing on a conceptual level. It is new to most students to start designing from a big idea of what could be, fitting within the retailers identity, to a detailed design that tells the story in each design aspect, taking consumer behavior into account. What we see is that they often start with smaller ideas which they want to combine in one whole. As a retail designer you need to guard the big idea and base every decision on it, so it is important to achieve that skill. Once taken that bridge, we noticed that the creativity of the design students together with the more theoretical view and communication skills of marketing students pushes the design one step forward towards more well-founded and relevant outcomes.

\section{FLASH-FORWARD}

Currently, we are in the 'tasting phase' of optimizing the summer school formula into a traveling one of 5 days (Monday-Friday) so more students, and teachers, are able to learn from this approach. The ambition to do this started with a question of one of our partner universities to organize a low-cost seamless retail design work-shop in their department, based on the summer school formula, including the same competencies. As a first experiment in testing how to teach these competencies in a contained short period of time we proposed a three-fold model that contains three different ways of learning. First, the students from the home university get to learn the craft of retail design in the most efficient way. Second, Master students from our university, that should know the craft, get to learn how to communicate it to others, in team. Indeed, literature on educating design shows that when students need to explain the knowledge they gained to other students the learning curve increases enormously. We notice a gap between knowing about retail design and applying what they know. Last, we felt the need of not only teach students about retail design but also teachers. Training the trainer is of course also a more sustainable way of spreading the knowledge. To this end, the tools we developed for the students, now come with a 'teachers manual'. The teacher of the home university is also asked to co-supervise the work-shop so all stakeholders can learn. So, our traveling model requires that the teacher will be joined by a small team of our master students (3 tot 5). The students help with the disseminating of the knowledge by being part of one or two groups, leaving more time for the teacher to train the trainer. Our master students are also evaluated on their skills as a team-member, as a knowledge disseminator and how they translate the theory into practice.

The content of the work-shop remains roughly the same, smaller assignments that need to be finished by the end of each day, cumulating into the final design. To be able to work efficient and to assess the competencies, we developed a template students need to follow when presenting.

Up to know we have tested the concept two times. Once in Politecnico di Milano, one of our summer school partners, and once in Cape Peninsula University of Technology (CPUT, Cape Town). Figure 1 shows two examples of the outcome, both presented in the template.

Due to the positive evaluations, particularly on the structure and strict timing in combination with the tools, the formula and template will also be used in the upcoming summer school in August (2019).

\section{CONCLUSION}

We have used and developed the summer school as an experiment in which teachers and students were not only looking at what the store of the future should look like but 
also as an experiment in how to shift the more conservative thinking in retail design, as a mono-discipline originating from architecture, to a multi-disciplinary one. So, on pedagogical level we have tried to establish a framework in which theory and practice are joined into an educational program. However, the think thank that originated six years ago, still continues its search to how retailers should respond to the changed society and consumer behavior. This challenge remains relevant and the outcome will continue to change as the society also keeps changing. The set-up of the summer school was the hunch. After six years of organizing and adapting its formula the answer has become clear and is ready to be subjected to peer review. Though this paper is not focussing on the answer of the question (the results of the design assignment), it is about the process and mind shift traditional architects and interior architects need to make in order to help the retailer stay relevant in todays conjunctuur. Students are given time to collectively reflect during one week on the store of tomorrow, which is often even more than a design agency can do. The results of each summer school are published in professional literature (retail journals) so all stakeholders connected to retail in general the can benefit from the students insights.

\section{REFERENCES}

Quartier, Katelijn, Lommelen, Tinne, and Jan Vanrie, 2016. "Retailing and design: Combining the best of both worlds". In MultiChannel Marketing, Branding and Retail Design: New Challenges and Opportunities, edited by Charles Mclntyre, T. C. Melewar, Charles Dennis, 31-49. UK: Emerald Group Publishing Limited.

Quartier, Katelijn, 2017. "Retail Design: What's in the Name?". In Retail Design: Theoretical Perspectives, edited by Ann Petermans, Tony Kent, 31-48. UK: Routledge.

Rigby, Darrell, 2014. "E-commerce is Not Eating Retail". Business Harvard Review. Accessed July 4, 2019. https://hbr. org/2014/08/e-commerce-is-not-eating-retail

Van Ossel, Gino, 2014. Omnichannel in retail: het antwoord op e-commerce. Tielt: Uitgeverij Lannoo.

Van Tongeren, Michel, 2013. One to One: The Essence of Retail Branding and Design. Amsterdam: BIS Publishers.

Zimmermann, Rainer, and Teufel, Philipp, 2015. Holistic Retail

Design: Reshaping Shopping for the Digital Era. Amsterdam: Frame Publishers.

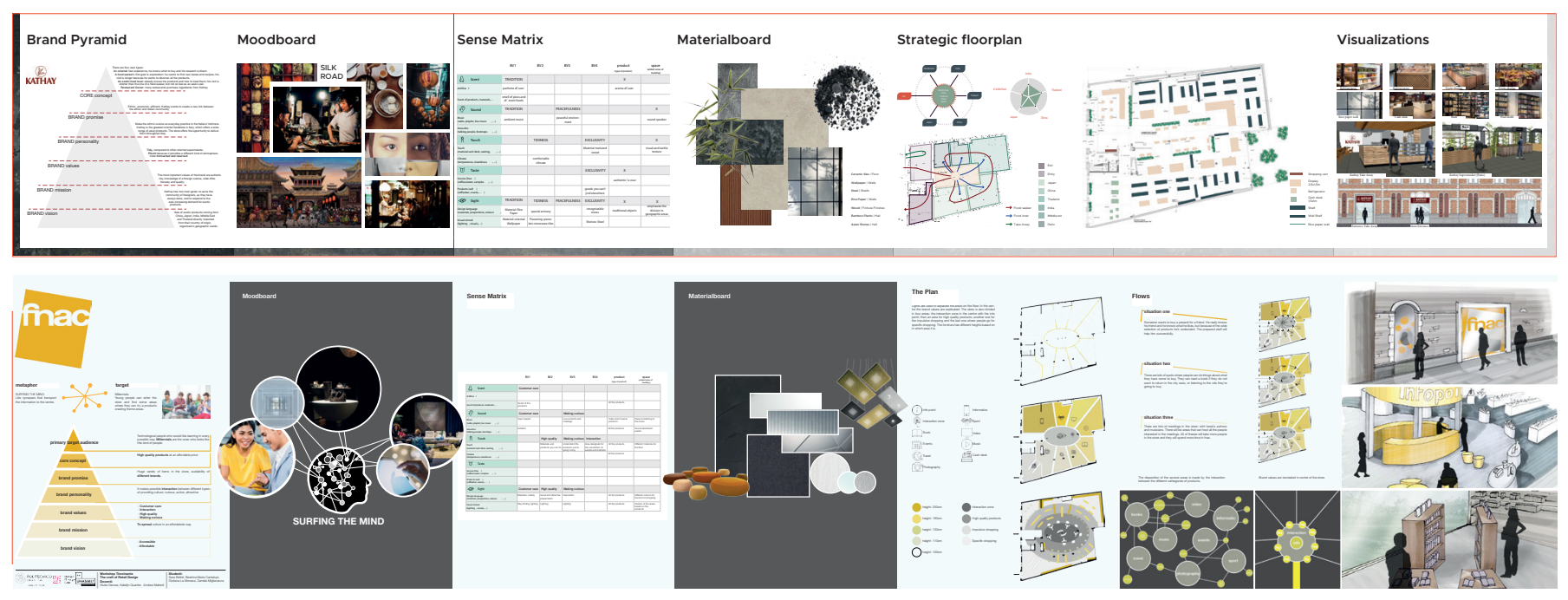

Firgure 1. The template containing the brand pyramid, moodboard, sense matrix, materialboard, strategic floorpan and visualizations for Fnac and Kathay (both projects done by students of Polimi). 